\title{
Kandydowanie sekretarzy i skarbników gmin, powiatów oraz województw w wyborach na urząd wójta, burmistrza lub prezydenta miasta ${ }^{1}$
}

Secretaries and treasurers of communes, districts and voivodeships as candidates for a head of commune, a mayor or a president of the city (WAKiU-2604/17): In accordance with the Electoral Code a person employed as a secretary or a treasurer of a commune (district, voivodeship) has a right to stand for election for a head of commune, a mayor and a president of the city. However, combining the function of a secretary or a treasurer with the post of the head of commune, the mayor or the president of the city in a single or in different local self-government units is inadmissible Self-local government officials employed on official posts are restricted, during a potential election campaign, by their labour duties, in particular they are not allowed to undertake activities "causing reasonable suspicion of partiality or acting in self-interest" as well as they cannot disclose information constituting a statutorily protected secret learned with in connection with the performed professional duties.

Keywords: commune, district, local self-government, voivodeship, election

Słowa kluczowe: gmina, powiat, samorząd terytorialny, województwo, wybory

Doktor nauk prawnych, starszy wykładowca na Uniwersytecie Jagiellońskim, ekspert ds. legislacji BAS; piotr.czarny@neostrada.pl.

\section{Zagadnienia wstępne}

Przedmiotem niniejszej opinii prawnej jest odpowiedź na pytanie: „Czy zgodnie z ustawą z 5 stycznia 2011 r. Kodeks wyborczy (Dz.U. nr 21 poz. 112, ze zm.), ustawą z 8 marca 1990 r. o samorządzie gminnym (Dz.U. nr 16, poz. 95, ze zm.) ustawą z 5 czerwca o 1998 r. o samorządzie powiatowym (Dz.U. nr 91 poz. 578, ze zm.) oraz ustawą z 5 czerwca 1998 r. o samorządzie województwa (Dz.U. nr 91 poz. 576), uwzględniając ustawy nowelizujące ww. ustawy uchwalone przez Sejm 14 grudnia 2017 r., występują negatywne przesłanki uniemożliwiające osobom

1 Opinia sporządzona 9 stycznia 2018 r. na zlecenie Klubu Parlamentarnego Polskiego Stronnictwa Ludowego; BAS-WAKiU 2604/17. 
zajmującym stanowisko skarbnika oraz sekretarza gminy/powiatu/województwa bierny udział w wyborach do organu wykonawczego gminy wiejskiej, gminy miejskiej, gminy miejsko-wiejskiej, gminy miejskiej na prawach powiatu?".

Zacytowane pytanie nie jest sformułowane w sposób jednoznaczny przede wszystkim ze względu na użycie wyrażenia „bierny udział w wyborach”, którego znaczenie nie jest jasne. W dalszych rozważaniach przyjęto założenie, że chodzi o bierne prawo wyborcze (prawo kandydowania) w wyborach na urząd wójta, burmistrza lub prezydenta miasta. Zwrócić też należy uwagę, że przepisy Kodeksu wyborczego ${ }^{2}$ jednolicie regulują kwestię prawa wybieralności w wyborach na urząd wójta, burmistrza i prezydenta miasta bez względu na to, jaki jest status konkretnej gminy (tzw. gminy wiejskie, miasta, miasta na prawach powiatu).

\section{Uzasadnienie i ustalenia szczegółowe}

1. Punktem wyjścia dla odpowiedzi na pytanie jest treść art. 11 Kodeksu wyborczego, który dotyczy biernego prawa wyborczego we wszystkich wyborach powszechnych, a więc również w wyborach wójtów, burmistrzów i prezydentów miast. Zgodnie z art. $11 \$ 1$ pkt 6 Kodeksu w wyborach wójta (burmistrza, prezydenta miasta) prawo wybieralności ma obywatel polski mający prawo wybierania w tych wyborach, który najpóźniej w dniu głosowania kończy 25 lat, z tym że kandydat nie musi stale zamieszkiwać na obszarze gminy, w której kandyduje. $\mathrm{Z}$ kolei prawo wybierania (czynne prawo wyborcze) w tych wyborach przysługuje osobom mającym prawo wybierania do rady tej gminy, czyli obywatelom polskim oraz obywatelom Unii Europejskiej niebędącym obywatelami polskimi, którzy najpóźniej w dniu głosowania kończą 18 lat, oraz stale zamieszkują na obszarze danej gminy (art. $10 \$ 1$ pkt 3 i 4 Kodeksu wyborczego). Prawa wybieralności na urząd wójta, burmistrza lub prezydenta miasta pozbawione są osoby, które nie mają czynnego prawa wyborczego, a konkretnie chodzi o: a) pozbawionych praw publicznych prawomocnym orzeczeniem sądu; b) pozbawionych praw wyborczych prawomocnym orzeczeniem Trybunału Stanu; c) ubezwłasnowolnionych prawomocnym orzeczeniem sądu (art. $10 \S 2$ Kodeksu wyborczego).

Poza tym prawa wybieralności (a więc „tylko” biernego prawa wyborczego) nie mają osoby: a) skazane prawomocnym wyrokiem na karę pozbawienia wolności za przestępstwo umyślne ścigane z oskarżenia publicznego lub umyślne przestępstwo skarbowe; b) wobec których wydano prawomocne orzeczenie sądu stwierdzające utratę prawa wybieralności, o którym mowa w art. 21a ust. 2a ustawy z 18 października 2006 r. o ujawnianiu informacji o dokumentach or-

Ustawa z 5 stycznia 2011 r. - Kodeks wyborczy, Dz.U. nr 21, poz. 113, ze zm.; dalej: Kodeks wyborczy. 
ganów bezpieczeństwa państwa z lat 1944-1990 oraz treści tych dokumentów (Dz.U. 2016, poz. 1721).

Jak łatwo zauważyć, z przepisów powyższych wynika jednoznacznie, że osoby zatrudnione na stanowiskach sekretarzy lub skarbników gmin, powiatów i województw jako takie nie są pozbawione biernego prawa wyborczego w wyborach na urząd wójta, burmistrza lub prezydenta miasta. Wspomnieć tylko na marginesie należy o tym, że kandydat na wójta nie może jednocześnie kandydować na wójta w innej gminie (art. 472 Kodeksu wyborczego).

Regulacja zawarta w art. 11 Kodeksu wyborczego ma w założeniu charakter kompleksowy i „całościowy”, ponieważ użycie w tytule ustawy nazwy kodeks oznacza, że wyczerpująco reguluje ona obszerną dziedzinę spraw ( $\$ 19$ pkt 2 Zasad techniki prawodawczej - załącznika do rozporządzenia Prezesa rady Ministrów z 20 czerwca 2002 r. w sprawie „Zasad techniki prawodawczej”, t.j. Dz.U. 2016, poz. 283). Oznacza to, że w innych aktach normatywnych nie powinny być zawarte przepisy, które zmieniałyby lub uzupełniały treść kodeksu.

Podkreślić również należy, że Konstytucja RP reguluje w sposób precyzyjny kwestię czynnego prawa wyborczego w wyborach samorządowych. Zgodnie bowiem $\mathrm{z}$ art. 62 ust. 1 obywatel polski, który najpóźniej w dniu głosowania kończy 18 lat, ma prawo wybierania przedstawicieli do organów samorządu terytorialnego. Odstępstwa od tej zasady przewidziane są w ust. 2. Obowiązująca ustawa zasadnicza nie reguluje natomiast wprost problematyki zakresu biernego prawa wyborczego zarówno w wyborach do organów stanowiących jednostek samorządu terytorialnego, jak i w wyborach na urząd wójta, burmistrza lub prezydenta miasta. Zagadnienie to winno być więc przedmiotem regulacji ustawowej, która respektować powinna konstytucyjne zasady: powszechności wyborów, prawa dostępu do służby publicznej na jednakowych zasadach (art. 60) oraz założenia, zgodnie z którą „ogół mieszkańców jednostek zasadniczego podziału terytorialnego stanowi z mocy wspólnotę samorządową" (art. 16 ust. 1).

2. Uchwalona przez Sejm w dniu 14 grudnia 2017 r. ustawa o zmianie niektórych ustaw $\mathrm{w}$ celu zwiększenia udziału obywateli w procesie wybierania, funkcjonowania i kontrolowania niektórych organów publicznych ${ }^{3}$ wprowadziła pewne modyfikacje, jeśli chodzi o bierne prawo wyborcze $\mathrm{w}$ wyborach na urząd wójta, burmistrza i prezydenta miasta. Zgodnie z „nowym” art. $11 \$ 4$ Kodeksu wyborczego prawa wybieralności w wyborach wójta w danej gminie nie będzie miała osoba, która została uprzednio dwukrotnie wybrana na wójta $\mathrm{w}$ tej gminie w wyborach wójta zarządzonych na podstawie art. $474 \$ 1$. Poza tym w myśl wprowadzonego do Kodeksu wyborczego art. $472 \S 2$ kandydat na wójta nie będzie mógł jednocześnie kandydować do rady powiatu i do sejmiku województwa, będzie natomiast mógł kandydować do rady gminy tylko na ob-

Http://orka.sejm.gov.pl/opinie8.nsf/nazwa/2001_u/\$file/2001_u.pdf [dostęp 4 stycznia 2018 r.]. 
szarze gminy, w której kandyduje na wójta. Senat do rozwiązań tych nie wniósł poprawek $^{4}$.

W toku prac sejmowych nad projektem ustawy o zmianie niektórych ustaw w celu zwiększenia udziału obywateli w procesie wybierania, funkcjonowania i kontrolowania niektórych organów publicznych toczących się w Komisji nadzwyczajnej do rozpatrzenia projektów ustaw z zakresu prawa wyborczego zgłoszono poprawkę, zgodnie z którą w ustawie z 21 listopada 2008 r. o pracownikach samorządowych w art. 5 ust. 5 miał otrzymać brzmienie: „5. Sekretarz nie ma prawa tworzenia partii politycznych ani przynależności do nich oraz kandy-

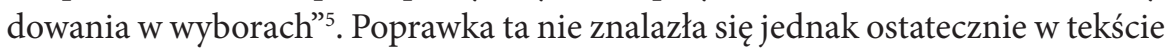
wyżej opisanej ustawy. Oznacza to, że w zakresie tematu niniejszej opinii stan prawny nie ulegnie zmianie po (ewentualnym) wejściu w życie ustawy z 14 grudnia 2017 r. nowelizującej Kodeks wyborczy.

3. Ustawy regulujące ustrój i organizację wewnętrzną jednostek samorządu terytorialnego wspominają zarówno o stanowisku sekretarza, jak i skarbnika jednostek samorządu terytorialnego. W świetle ustawy o samorządzie gminnym wójt może powierzyć prowadzenie określonych spraw gminy w swoim imieniu zastępcy wójta lub sekretarzowi gminy (art. 33 ust. 4.), z kolei skarbnik gminy określony został jako główny księgowy budżetu (art. 18 ust. 2 pkt 3). Według ustawy o samorządzie powiatowym sekretarz i skarbnik uczestniczą w pracach zarządu powiatu oraz mogą uczestniczyć w obradach rady powiatu i jej komisji z głosem doradczym (art. 37 ust. 2). Natomiast według art. 44 ust. 2 ustawy o samorządzie województwa skarbnik województwa uczestniczy w pracach oraz obradach zarządu województwa i sejmiku województwa z głosem doradczym.

Poza tym przepisy wspomnianych wyżej trzech ustaw ustrojowych regulują szczegółowo problematykę składania przez sekretarzy i skarbników oświadczeń majątkowych oraz ograniczenia w prowadzeniu przez nich działalności gospodarczej. Nie odnoszą się natomiast do kwestii przysługujących im praw wyborczych, co jest logiczne, ponieważ zasady i tryb przeprowadzania wyborów do rad gmin, powiatów i sejmików województw oraz wyboru wójta (burmistrza, prezydenta miasta) określa Kodeks wyborczy.

Przepisów tego rodzaju nie ma również w ustawie o pracownikach samorządowych, a do tej kategorii funkcjonariuszy publicznych należą wszyscy skarbnicy i sekretarze jednostek samorządu terytorialnego. Co prawda, w art. 5 ust. 5 tej ustawy znajduje się adresowany do sekretarzy gmin, powiatów i województw zakaz tworzenia partii politycznych i przynależności do nich, jednak nie może on być interpretowany w sposób rozszerzający. Sąd Najwyższy w uzasadnieniu wyroku z 7 lutego 2013 r. (sygn. III PK 25/12, niepubl.) wyraźnie zaznaczył, że

$4 \quad$ Http://orka.sejm.gov.pl/Druki8ka.nsf/0/5CE45A3377705864C12581FE00486177/\%2 4File/2143.pdf [dostęp 4 stycznia 2018 r.].

5 Http://sejm.gov.pl/Sejm8.nsf/biuletyn.xsp?skrnr=NPW-3 [dostęp 3 stycznia 2018 r.]. 
kandydowanie sekretarza gminy w wyborach samorządowych nie jest zakazane przez powołany wyżej przepis. Przytoczyć tu również należy pogląd wyrażony przez Wojewódzki Sąd Administracyjny we Wrocławiu w wyroku z 6 września 2011 r. (sygn. III SA/Wr 294/11, LEX nr 966617): (...) fakt kandydowania na radnego $z$ listy określonej partii, $z$ której programem radny się solidaryzuje, nie może stanowić podstawy do skutecznego formułowania zarzutu naruszenia interpretowanego przepisu [tj. art. 5 ust. 5 ustawy o pracownikach samorządowych. dopisek P.C.]. Określony w nim zakaz jest bowiem nadzwyczaj jasny i konkretny. Nie dopuszcza interpretacji rozszerzajacej, zwłaszcza zastępowania go - przy zastosowaniu swoistej „żonglerki słownej” - obszernym i ogólnikowym zakazem całkowitej „apolityczności”. W wyroku tym podkreślono również, że: Przepis art. 5 ust. 5 ustawy z 2008 r. o pracownikach samorzadowych nie nakazuje wszak sekretarzowi jakiejkolwiek jednostki samorzadu terytorialnego catkowitej „apolityczności", w rozumieniu wyzbycia się wszelkich pogladów i sympatii politycznych oraz ich ewentualnego wyrażania na zewnatrz. Zakazuje wyłacznie „tworzenia partii politycznych" i „przynależności do nich".

Oznacza to w konsekwencji, że również ustawa o pracownikach samorządowych nie może być podstawą do formułowania zakazu kandydowania sekretarzy i skarbników gmin, powiatów lub województw w wyborach na urząd wójta, burmistrza lub prezydenta miasta.

4. Od zakazu kandydowania na określone stanowisko odróżnić należy tzw. niepołączalność (incompatibilitas). Oczywiste jest, że jedna osoba nie może łączyć stanowiska wójta (burmistrza, prezydenta miasta) ze stanowiskiem skarbnika lub sekretarza zarówno danej gminy, jak i innych jednostek samorządu terytorialnego. Jednak generalnie przyjmuje się, że zakazy dotyczące łączenia stanowisk w żadnym stopniu nie ograniczają możliwości ubiegania się o stanowiska lub funkcje publiczne, ponieważ zakazy w tym drugim zakresie muszą być wyraźnie i jednoznacznie sformułowane w przepisach rangi ustawowej. Stąd też niepołączalność stanowiska wójta, burmistrza lub prezydenta miasta $\mathrm{z}$ funkcją sekretarza lub skarbnika jednostki samorządu terytorialnego powoduje jedynie, że w razie wyboru należy doprowadzić do zniesienia „kolizji”. Gdyby więc osoba zajmująca stanowisko sekretarza lub skarbnika kandydowała w wyborach na urząd wójta, burmistrza lub prezydenta miasta i została wybrana, winna ona przez zrzeczenie się zajmowanego stanowiska doprowadzić do stanu zgodności z prawem (art. $492 \$ 4$ Kodeksu wyborczego).

5. Na marginesie zwrócić należy uwagę, że zgodnie $\mathrm{z}$ art. 30 ust. 1 ustawy o pracownikach samorządowych pracownik samorządowy zatrudniony na stanowisku urzędniczym, w tym kierowniczym stanowisku urzędniczym, nie może wykonywać zajęć pozostających w sprzeczności lub związanych z zajęciami, które wykonuje w ramach obowiązków służbowych, wywołujących uzasadnione podejrzenie o stronniczość lub interesowność, oraz zajęć sprzecznych z obowiązkami wynikającymi z ustawy. Sekretarz i skarbnik gminy (powiatu, woje- 
wództwa) są pracownikami samorządowymi zatrudnionymi na stanowiskach urzędniczych, a wobec tego obowiązuje ich powyższy zakaz, który odnosi się również do zajęć o charakterze niezarobkowym. Oznacza to pewne ograniczenia, jeśli chodzi o sposób prowadzenia kampanii wyborczej przez kandydatów, będących pracownikami samorządowymi. Nie może on bowiem rodzić uzasadnionych podejrzeń o stronniczość lub interesowność w wypełnianiu zadań urzędowych. Oczywiste jest również, że pracownik samorządowy nie może prowadzić kampanii wyborczej „w godzinach pracy”, jak również to, że w jej toku nie może ujawniać informacji, stanowiących tajemnice ustawowo chronione, o których dowiedział się w związku ze swoimi obowiązkami służbowymi.

Niezależnie od tego z powołanego wcześniej wyroku Sądu Najwyższego wynika, że sposób zaangażowania się pracownika samorządowego w kampanię wyborczą powodować może utratę zaufania ze strony wójta, starosty lub marszałka województwa koniecznego w ich relacjach z pracownikami urzędu gminy, starostwa lub urzędu marszałkowskiego. Szczególnie dotyczy to sekretarzy i skarbników jak i osób pełniących funkcje kierownicze. Powodować to może konsekwencje w postaci rozwiązania stosunku pracy lub przesunięcia na inne stanowisko. Dalsza analiza tego zagadnienia wykracza jednak poza zakres niniejszej opinii.

\section{Podsumowanie}

W podsumowaniu należy zaprezentować tezy, które wynikają z przedstawionych rozważań i analiz.

- Zgodnie z przepisami Kodeksu wyborczego osobie zatrudnionej na stanowisku sekretarza lub skarbnika gminy (powiatu, województwa) przysługuje bierne prawo wyborcze (prawo kandydowania) w wyborach na urząd wójta (burmistrza, prezydenta miasta). Zakaz kandydowania w tym przypadku nie wynika z żadnych ustaw ustrojowych regulujących status i działalność poszczególnych szczebli jednostek samorządu terytorialnego. Z ustawy o pracownikach samorządowych wynika jedynie zakaz przynależności sekretarzy gmin (powiatów, województw) do partii politycznych, jednak nie można interpretować go rozszerzająco i odnosić do biernego prawa wyborczego.

- W opisanym zakresie stan prawny nie ulegnie zmianie po (ewentualnym) wejściu w życie ustawy z 14 grudnia 2017 r. o zmianie niektórych ustaw w celu zwiększenia udziału obywateli w procesie wybierania, funkcjonowania i kontrolowania niektórych organów publicznych. W toku prac ustawodawczych zgłaszane były poprawki dotyczące zakazu kandydowania w wyborach sekretarzy gmin (powiatów, województw), nie zostały one jednak uwzględnione w tekście ustawy przyjętej przez Sejm ani w poprawkach zgłoszonych przez Senat.

- Prawnie niedopuszczalne jest łączenie stanowiska wójta (burmistrza, prezydenta miasta) z funkcją sekretarza lub skarbnika (gminy, powiatu i woje- 
wództwa) zarówno w jednej, jak i w różnych jednostkach samorządu terytorialnego. Powoduje to pewne komplikacje prawne w sytuacji wyboru osoby zajmującej stanowisko sekretarza lub skarbnika gminy (powiatu lub województwa) na urząd wójta, burmistrza lub prezydenta. Zakaz łączenia stanowisk nie jest jednak tożsamy z zakazem kandydowania.

- Zarówno sekretarzy, jak i skarbników jednostek samorządu terytorialnego jako pracowników samorządowych zatrudnionych na stanowiskach urzędniczych obowiązują $\mathrm{w}$ toku prowadzenia ewentualnej kampanii wyborczej ograniczenia wynikające $\mathrm{z}$ ich powinności pracowniczych w urzędzie gminy (powiatu, województwa), w szczególności zaś zakaz podejmowania działań „wywołujących uzasadnione podejrzenie o stronniczość lub interesowność" i ujawniania informacji stanowiących tajemnicę ustawowo chronioną, które uzyskali w związku z pełnieniem obowiązków służbowych. 